\title{
Albendazole, levamisole and ivermectin are effective against monogeneans of Colossoma macropomum (Pisces: Serrasalmidae)
}

\author{
Carliane Maria Guimarães Alves $^{1}$ ｜ Joziele Neves Nogueira ${ }^{2}$ ～Isaac Belo Barriga ${ }^{2}$ | \\ Joilson Rodrigues dos Santos ${ }^{3}$ | Gracienhe Gomes Santos ${ }^{3}$ | Marcos Tavares-Dias ${ }^{1,4}$
}

${ }^{1}$ Postgraduate Program in Environmental Sciences (PPGCA), Federal University of Amapá (UNIFAP), Macapá, Brazil

${ }^{2}$ University of the State of Amapá (UEAP), Macapá, Brazil

${ }^{3}$ Faculdade de Macapá (FAMA), Macapá, Brazil

${ }^{4}$ Embrapa Amapá, Macapá, Brazil

\section{Correspondence}

Marcos Tavares-Dias, Postgraduate Program in Environmental Sciences (PPGCA), Federal University of Amapá (UNIFAP), Macapá, Brazil.

Email: marcos.tavares@embrapa.br

Funding information

Conselho Nacional de Desenvolvimento Científico e Tecnológico, Grant/Award Number: 303013/2015-0

\begin{abstract}
This study evaluated the efficacy of albendazole, ivermectin, levamisole, mebendazole and praziquantel on monogeneans of Colossoma macropomum, based on in vitro and in vivo assays. In vitro assays indicated that albendazole (500, 100, 1,500 and 2,000 mg/L), ivermectin (200, 250, 300 and $350 \mathrm{mg} / \mathrm{L})$ and levamisole (50, 75, 100 and $125 \mathrm{mg} / \mathrm{L}$ ) were 100\% effective against Anacanthorus spatulatus, Notozothecium janauachensis, Mymarothecium boegeri and Linguadactyloides brinkmanni, while mebendazole (125, 150, 175 and $200 \mathrm{mg} / \mathrm{L})$ and praziquantel (5, 10, 15 and $20 \mathrm{mg} / \mathrm{L})$ were ineffective. Fish mortality in $24 \mathrm{hr}$ therapeutic baths with $500 \mathrm{mg} / \mathrm{L}$ of albendazole was $6.6 \%$, but the behaviour of the animals remained unchanged, while $200 \mathrm{mg} / \mathrm{L}$ of ivermectin caused lethargy, signs of hypoxia and $100 \%$ mortality within $2 \mathrm{hr}$, and $125 \mathrm{mg} / \mathrm{L}$ of levamisole caused no mortality. The efficacy of $500 \mathrm{mg} / \mathrm{L}$ of albendazole was $48.6 \%$ in the $24 \mathrm{hr}$ baths, while that of $125 \mathrm{mg} / \mathrm{L}$ levamisole was $88.2 \%$. Although ivermectin showed in vitro efficacy, the lowest concentration used in baths was highly toxic to fish. Therefore, we recommend the use of $125 \mathrm{mg} / \mathrm{L}$ of levamisole to control and treat monogenean infestations on $C$. macropomum in fish farming.

KEYWORDS

anthelmintic, fish, infection, parasites, treatment
\end{abstract}

\section{1 | INTRODUCTION}

Human societies face the enormous challenge of having to provide food and livelihoods to a global population that is estimated to exceed 9 billion people by the mid-21st century. In 2016, the global commercial production of fish, $88 \%$ of it destined for human consumption, reached an all-time high of 171 million tons (USD 362 billion) thanks to the relatively stable volume of fish captured by commercial fishing, reduced wastage and the steady growth of fish farming, which contributed 80 million tons of fish (USD 231.6 billion). This production resulted in a record high annual per capita consumption of $20.3 \mathrm{~kg}$ in 2016 . The production of farmed fish in 2016 was of 54.1 million tons (FAO, 2018). However, all types of fish production are threatened by diseases caused by parasites such as monogeneans, resulting in significant economic losses (TavaresDias \& Martins, 2017). Monogeneans are parasites with a direct and short life cycle, whose vertical transmission facilitates infection levels in intensive fish farming (Morales-Serna et al., 2018). Therefore, increasing interest has focused not only on understanding these diseases in fish but also on treating them correctly, using commercially available, low-cost and effective anthelmintic drugs.

In intensive fish farming, managing and controlling helminth infections pose a constant challenge, since these tasks are greatly complicated by the limited availability of licensed anthelmintic drugs (Morales-Serna et al., 2018; Zuskova et al., 2018) with varying degrees of effectiveness. Anthelmintic drugs 
such as albendazole, mebendazole, ivermectin, levamisole and praziquantel have been employed for the control and treatment against monogenean parasites that infest farmed fish (Hirazawa, Akiyama, \& Umeda, 2013; Hirazawa, Ohtaka, \& Hata, 2000; Kim \& Choi, 1998; Martins, Onaka, Moraes, \& Fujimoto, 2001; MoralesSerna et al., 2018; Onaka, Martins, \& Moraes, 2003; Santamarina, Tojo, Ubeira, Quinteiro, \& Sanmartin, 1991; Sitjà-Bobadilla, Felipe, \& Alvarez-Pellitero, 2006; Zhang et al., 2014). Parasite infections can be controlled and treated by eliminating developmental stages in hosts, thus interrupting the life cycle of parasites (Bader, Chelladurai, Starling, Jones, \& Brewer, 2017). However, the concentrations of these different drugs must be not only safe and effective but also non-toxic to fish. In addition, all forms of parasite control require in-depth knowledge about the environment and water quality parameters in fish farming.

Various studies have demonstrated ivermectin toxicity in fish (Mladineo, Marsic-lucic, \& Buzancic, 2006; Santamarina et al., 1991; Thiripurasundari, Sathya, Uma, Srinivasan, \& Rajasekar, 2014; Varó et al., 2010), whereas clinical concentrations of albendazole, mebendazole, levamisole and praziquantel present a low toxicity (Hirazawa et al., 2013; Kim \& Choi, 1998; Martins et al., 2001; Onaka et al., 2003). However, these anthelminthics have not been assayed to ascertain their effectiveness in controlling monogeneans of Colossoma macropomum (tambaqui), a fish of great economic importance to aquaculture from the Amazon. Thus, the purpose of this study was to investigate the in vitro and in vivo efficacy of albendazole, ivermectin, levamisole, mebendazole and praziquantel against monogeneans of $C$. macropomum.

\section{2 | MATERIALS AND METHODS}

\section{1 | Fish and monogenean parasites}

Two hundred C. macropomum fingerlings ( $\pm 30 \mathrm{~g}$ ) from a commercial fish farming in the municipality of Macapá, state of Amapá, were taken to Embrapa's fish Aquaculture and Fishery Laboratory in Macapá (Brazil). In the laboratory, the fish were acclimatized for 7 days in $500 \mathrm{~L}$ tanks kept at a constant water pressure and were fed twice daily with fish feed containing $32 \%$ crude protein. The mean temperature in the tanks was $30.6 \pm 0.1^{\circ} \mathrm{C}$, dissolved oxygen content was $5.6 \pm 0.2 \mathrm{mg} / \mathrm{L}, \mathrm{pH}$ was $5.3 \pm 0.2$, total ammonia was $0.5 \pm 0.2 \mathrm{mg} / \mathrm{L}$, alkalinity was $10.0 \pm 0 \mathrm{mg} / \mathrm{L}$, and hardness was $10.0 \pm 0 \mathrm{mg} / \mathrm{L}$. These water parameters were monitored using a multiparameter probe (Horiba Mod. U52, Japan).

These fish were used for all in vitro and in vivo assays. The monogeneans were obtained from naturally infested fish.

\section{2 | Anthelmintic drugs}

A solution of Albendathor $10 \AA$ (Fabiani, Brazil) was used at a concentration of $10 \%$ albendazole. Ivomec Gold $\AA$ solution at a concentration of $3.15 \%$ ivermectin was obtained from Merial, Brazil. Ripercol
$150 \mathrm{~F}$ solution at a concentration of $18.8 \%$ levamisole was purchased from Zoetis, Brazil. Mebendasil $₫$ powder (100\%) containing $5 \mathrm{~g}$ of mebendazole was supplied by Vansil, Brazil, and praziquantel powder (100\%) was purchased from Shanxi Qianxiu Pharmaceutical Co. Ltd, China.

\section{3 | In vitro assays of anthelminthics against monogeneans of Colossoma macropomum}

Fifty C. macropomum fingerlings $(12.9 \pm 1.0 \mathrm{~cm}$ and $32.6 \pm 9.3 \mathrm{~g})$ were euthanized by medullary section and their parasitized gills removed in order to determine what duration of exposure to the four different concentrations of albendazole, ivermectin, levamisole, mebendazole and praziquantel would kill the monogeneans attached to the gills (Table 1). The various concentrations of albendazole, levamisole and ivermectin, diluted in water from the fish breeding tank to a volume of $5 \mathrm{~m} / \mathrm{L}$, were placed in Petri dishes $(5.5 \mathrm{~cm})$. Concentrations of mebendazole and praziquantel were diluted in $1.0 \mathrm{ml}$ of dimethyl sulfoxide (DMSO), and then, water from the breeding tank was added to make up $5 \mathrm{ml}$ in Petri dishes. Two control groups were prepared, one using $1.0 \mathrm{~m} / \mathrm{L}$ of DMSO as solvent in water from the fish breeding tank and the other using only water from the breeding tanks.

Each branchial arch of C. macropomum naturally parasitized by monogeneans was placed separately in a Petri dish and immersed in the different concentrations of albendazole, ivermectin, levamisole, mebendazole and praziquantel (Table 1). Under a stereomicroscope, fields of view containing \pm 20 monogeneans were selected in each repetition, and after submerging the branchial arches in the different concentrations of anthelminthics, the parasites were observed under the microscope at 5-min intervals to count the number of live and dead monogeneans. The parasites were considered dead when they were detached from the gill tissue or when they were attached to the gill tissue but had completely lost their mobility (Soares et al., 2017). The efficacy of each treatment was estimated as proposed by Zhang et al. (2014). We recorded the time it took to kill $100 \%$ of the monogeneans and hypothesized that a treatment was effective if $100 \%$ parasite mortality was achieved within 2 hr.

Based on the in vitro results, the best concentrations were used in therapeutic baths against monogeneans of $C$. macropomum.

TAB LE 1 Concentrations of the anthelmintic drugs used in the in vitro assays against monogeneans of Colossoma macropomum

\begin{tabular}{|lrrrr}
\hline Anthelmintic drugs & \multicolumn{5}{c}{ Concentrations (mg/L) } \\
\hline Albendazole & 500 & 1,000 & 1,500 & 2,000 \\
Levamisole & 50 & 75 & 100 & 125 \\
\hline Mebendazole & 125 & 150 & 175 & 200 \\
\hline Ivermectin & 200 & 250 & 300 & 350 \\
\hline Praziquantel & 5 & 10 & 15 & 20 \\
\hline
\end{tabular}




\subsection{In vivo assays of anthelminthics against monogeneans of Colossoma macropomum}

One hundred and twenty C.macropomum fingerlings (length: $15.5 \pm 1.1 \mathrm{~cm}$, weight: $55.9 \pm 12.0 \mathrm{~g}$ ) naturally parasitized by monogeneans were randomly distributed in twelve $100 \mathrm{~L}^{-1}$ tanks, which were kept in a static water system under constant aeration for $24 \mathrm{hr}$. The mean temperature in the tanks was $30.4 \pm 0.1^{\circ} \mathrm{C}$, dissolved oxygen content was $5.5 \pm 0.2 \mathrm{mg} / \mathrm{L}$, $\mathrm{pH}$ was $5.3 \pm 0.2$, total ammonia was $0.5 \pm 0.2 \mathrm{mg} / \mathrm{L}$, alkalinity was $10.0 \pm 0 \mathrm{mg} / \mathrm{L}$, and hardness was $10.0 \pm 0 \mathrm{mg} / \mathrm{L}$.

The therapeutic baths of $24 \mathrm{hr}$ consisted of four treatments ( 0 and $125 \mathrm{mg} / \mathrm{L}$ levamisole, 0 and $200 \mathrm{mg} / \mathrm{L}$ ivermectin and 0 and $500 \mathrm{mg} / \mathrm{L}$ albendazole) with three repetitions each, and 10 fish in each repetition, making a total of 30 fish per treatment. All
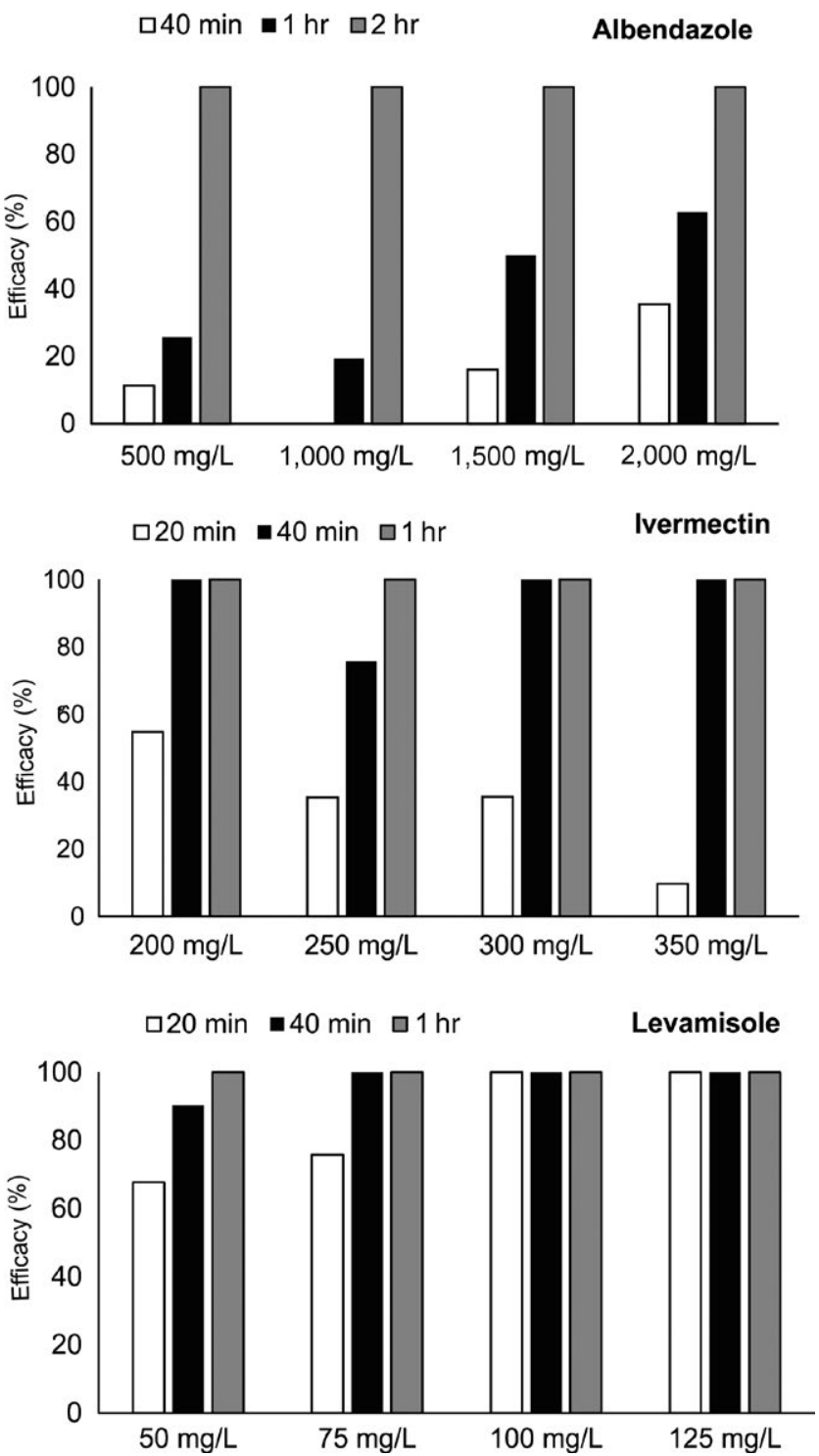

FIGURE 1 In vitro efficacy of anthelmintic drugs against monogeneans of Colossoma macropomum in different exposure times treatments were performed in parallel with the control group. Since none of the in vitro concentrations of levamisole, ivermectin and albendazole proved to be dose-dependent, the lowest concentrations were chosen to avoid toxicity in fish. During the bath of $24 \mathrm{hr}$, the behaviour of the fish was observed and they were not fed.

After the therapeutic baths with levamisole, ivermectin and albendazole, the fish were euthanized by medullary section and their gills were excised, fixed in 5\% formalin and examined under a stereomicroscope to identify and quantify the monogenean parasites. The parasites were prepared for identification as recommended by Eiras, Takemoto, and Pavanelli (2006). After quantification of the parasites, the prevalence and mean abundance and mean intensity of infestation were calculated as described by Bush, Lafferty, Lotz, and Shostak (1997) and the efficacy of each treatment as described by Sommerville et al. (2016).

\subsection{Statistical analyses}

The abundance data of the bath treatments were evaluated based on the Shapiro-Wilk normality test and Bartlett's test of homoscedasticity. Because the intensity and abundance data were not normally distributed, they were analysed by the Kruskal-Wallis test, followed by Dunn's test for comparison among medians. The efficacy of albendazole and levamisole was compared using the $t$ test (Zar, 2010).

\section{3 | RESULTS}

In vitro assays, all the albendazole concentrations caused immobilization $100 \%$ of the monogeneans of $C$. macropomum (Anacanthorus

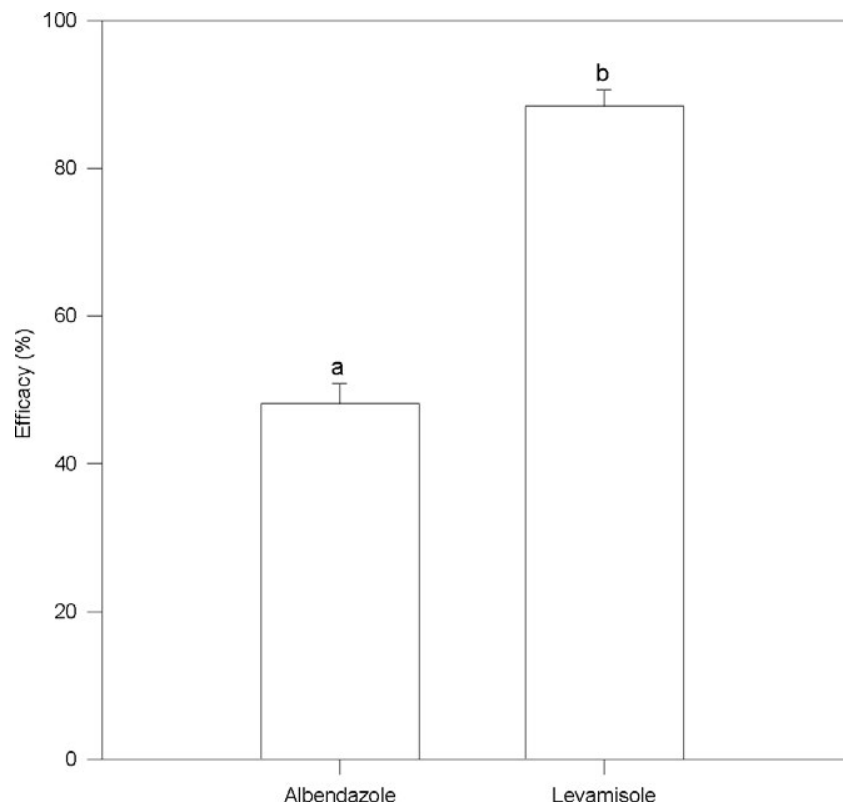

FIGURE 2 Therapeutic baths efficacy with $500 \mathrm{mg} / \mathrm{L}$ of albendazole and $125 \mathrm{mg} / \mathrm{L}$ levamisole in monogeneans of Colossoma macropomum after $24 \mathrm{hr}$ of treatment. Mean values followed by different letters indicate differences between treatments according to $t$ test $(p<0.05)$ 
TAB LE 2 In vitro efficacy of the concentrations of anthelminthics against monogeneans of Colossoma macropomum in different exposure times

\begin{tabular}{|c|c|c|c|}
\hline Exposure time & Treatments & Live parasites & Mortality (\%) \\
\hline $0 \mathrm{hr}$ & Water of tank & $20.7 \pm 0.6$ & 0 \\
\hline $1 \mathrm{hr}$ & Water of tank & $20.7 \pm 0.6$ & 0 \\
\hline $6 \mathrm{hr}$ & Water of tank & 0 & 100 \\
\hline $0 \mathrm{hr}$ & DMSO & $20.0 \pm 0$ & 0 \\
\hline $40 \mathrm{~min}$ & DMSO & $4.0 \pm 4.0$ & 80.0 \\
\hline $1 \mathrm{hr}$ & DMSO & 0 & 100 \\
\hline $0 \mathrm{hr}$ & $500 \mathrm{mg} / \mathrm{L}$ of albendazole & $26.0 \pm 1.7$ & 0 \\
\hline $20 \mathrm{~min}$ & $500 \mathrm{mg} / \mathrm{L}$ of albendazole & $19.3 \pm 1.1$ & 5 \\
\hline $40 \mathrm{~min}$ & $500 \mathrm{mg} / \mathrm{L}$ of albendazole & $18.3 \pm 1.5$ & 9.8 \\
\hline $20 \mathrm{~min}$ & $1,000 \mathrm{mg} / \mathrm{L}$ of albendazole & $22.0 \pm 1.0$ & 0 \\
\hline $40 \mathrm{~min}$ & $1,000 \mathrm{mg} / \mathrm{L}$ of albendazole & $20.7 \pm 1.1$ & 6.1 \\
\hline $1 \mathrm{hr}$ & $1,000 \mathrm{mg} / \mathrm{L}$ of albendazole & $16.7 \pm 3.0$ & 24.2 \\
\hline $2 \mathrm{hr}$ & $1,000 \mathrm{mg} / \mathrm{L}$ of albendazole & 0 & 100 \\
\hline $0 \mathrm{hr}$ & $1,500 \mathrm{mg} / \mathrm{L}$ of albendazole & $20.0 \pm 0$ & 0 \\
\hline $20 \mathrm{~min}$ & $1,500 \mathrm{mg} / \mathrm{L}$ of albendazole & $20.0 \pm 0$ & 0 \\
\hline $40 \mathrm{~min}$ & $1,500 \mathrm{mg} / \mathrm{L}$ of albendazole & $17.3 \pm 2.3$ & 13.3 \\
\hline $1 \mathrm{hr}$ & $1,500 \mathrm{mg} / \mathrm{L}$ of albendazole & $10.3 \pm 8.5$ & 48.3 \\
\hline $0 \mathrm{hr}$ & $200 \mathrm{mg} / \mathrm{L}$ of ivermectin & $21.6 \pm 1.5$ & 0 \\
\hline $20 \mathrm{~min}$ & $200 \mathrm{mg} / \mathrm{L}$ of ivermectin & $9.3 \pm 4.0$ & 57.0 \\
\hline $40 \mathrm{~min}$ & $200 \mathrm{mg} / \mathrm{L}$ of ivermectin & 0 & 100 \\
\hline $\mathrm{O} \mathrm{hr}$ & $250 \mathrm{mg} / \mathrm{L}$ of ivermectin & $20.3 \pm 0.6$ & 0 \\
\hline $20 \mathrm{~min}$ & $250 \mathrm{mg} / \mathrm{L}$ of ivermectin & $13.3 \pm 4.9$ & 34.4 \\
\hline $40 \mathrm{~min}$ & $250 \mathrm{mg} / \mathrm{L}$ of ivermectin & $5.0 \pm 5.0$ & 75.4 \\
\hline $1 \mathrm{hr}$ & $250 \mathrm{mg} / \mathrm{L}$ of ivermectin & 0 & 100 \\
\hline $\mathrm{O} \mathrm{hr}$ & $300 \mathrm{mg} / \mathrm{L}$ of ivermectin & $21.6 \pm 1.5$ & 0 \\
\hline $20 \mathrm{~min}$ & $300 \mathrm{mg} / \mathrm{L}$ of ivermectin & $11.6 \pm 2.9$ & 46.1 \\
\hline $40 \mathrm{~min}$ & $300 \mathrm{mg} / \mathrm{L}$ of ivermectin & 0 & 100 \\
\hline $\mathrm{O} \mathrm{hr}$ & $350 \mathrm{mg} / \mathrm{L}$ of ivermectin & $23.7 \pm 1.1$ & 0 \\
\hline $20 \mathrm{~min}$ & $350 \mathrm{mg} / \mathrm{L}$ of ivermectin & $18.6 \pm 3.2$ & 46.1 \\
\hline $40 \mathrm{~min}$ & $350 \mathrm{mg} / \mathrm{L}$ of ivermectin & 0 & 100 \\
\hline $0 \mathrm{hr}$ & $50 \mathrm{mg} / \mathrm{L}$ of levamisole & $22.0 \pm 2.0$ & 0 \\
\hline $20 \mathrm{~min}$ & $50 \mathrm{mg} / \mathrm{L}$ of levamisole & $6.7 \pm 5.8$ & 69.7 \\
\hline $40 \mathrm{~min}$ & $50 \mathrm{mg} / \mathrm{L}$ of levamisole & $2.0 \pm 2.0$ & 90.9 \\
\hline
\end{tabular}


TABLE 2 (Continued)

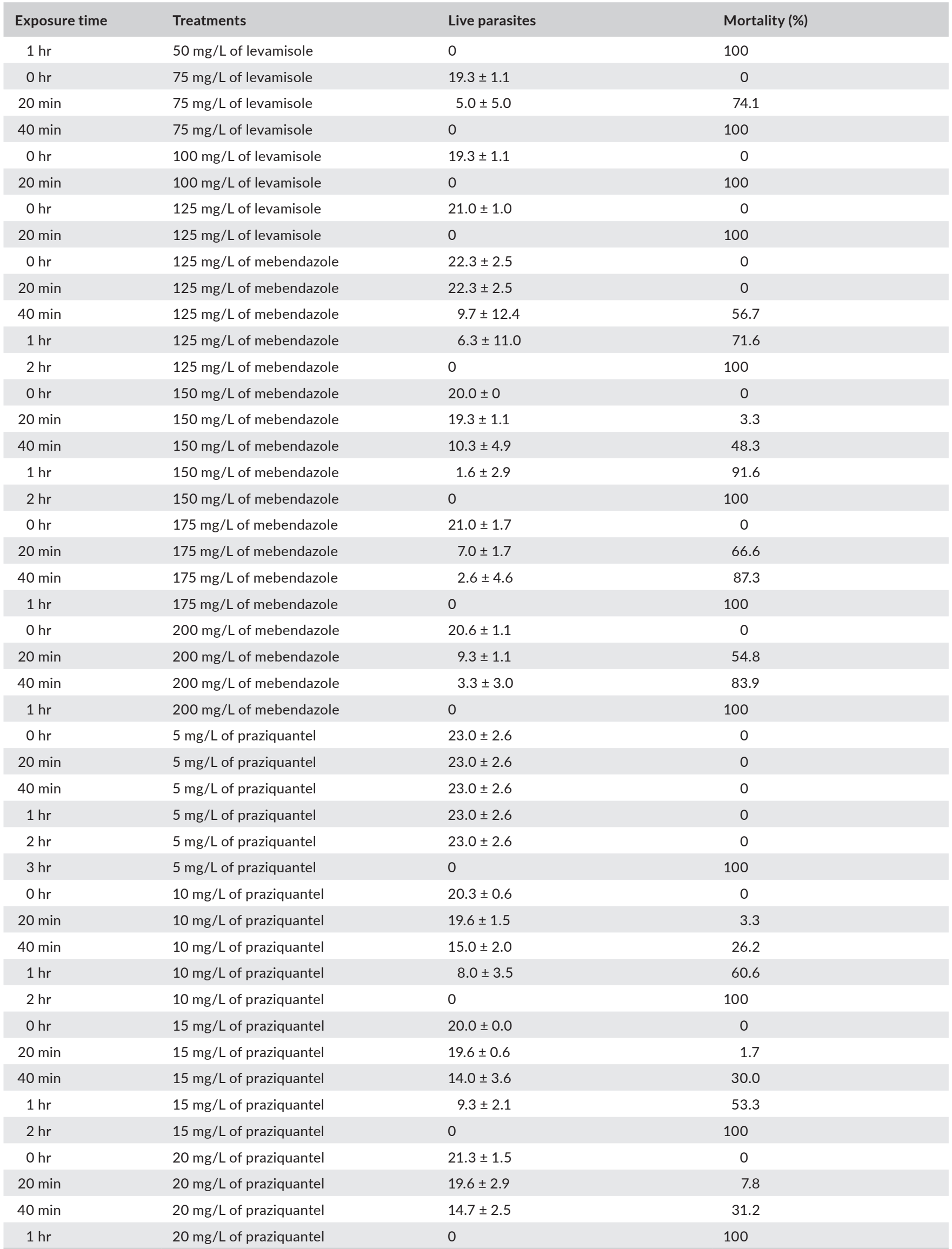


spatulatus, Notozothecium janauachensis, Mymarothecium boegeri and Linguadactyloides brinkmanni) after $2 \mathrm{hr}$ of exposure, while concentrations of 200,300 and $350 \mathrm{mg} / \mathrm{L}$ of ivermectin caused immobilization of the parasites after 40 min of exposure. Levamisole concentrations of 100 and $125 \mathrm{mg} / \mathrm{L}$ caused total immobilization of the parasites in just 20 min of exposure. Mebendazole concentrations of 175 and $200 \mathrm{mg} / \mathrm{L}$ and all the praziquantel concentrations also caused immobilization $100 \%$ of the parasites. Moreover, the parasites in the control groups exposed to DMSO also suffered immobilization $100 \%$. In the controls treated with water from the breeding tank, the monogeneans showed immobilization $100 \%$ only after $6 \mathrm{hr}$ of exposure (Table 2). Thus, only albendazole, ivermectin and levamisole showed in vitro efficacy against monogeneans of C. macropomum (Figure 1), since mebendazole and praziquantel efficacy were influenced by the solvent DMSO.

Anacanthorus spatulatus, N. janauachensis, M. boegeri and L. brinkmanni were also identified on gills of $C$. macropomum used in the therapeutic baths. A high prevalence of monogeneans was observed in the fish of therapeutic baths with levamisole, albendazole and controls. The prevalence of A. spatulatus in baths with $500 \mathrm{mg} / \mathrm{L}$ of albendazole was similar to that of the controls in water from the breeding tank (Table 3). The therapeutic baths containing $500 \mathrm{mg} / \mathrm{L}$ of albendazole showed $48.6 \%$ antiparasitic efficacy, while those containing $125 \mathrm{mg} / \mathrm{L}$ of levamisole showed 88.2\% efficacy (Figure 2). Moreover, the intensity of monogeneans in control treatments was higher $(H=60.5, p=0.0001)$ than in treatment with $500 \mathrm{mg} / \mathrm{L}$ of albendazole and $125 \mathrm{mg} / \mathrm{L}$ of levamisole.

Colossoma macropomum exhibited lethargy and signs of hypoxia after $1 \mathrm{hr}$ of therapeutic baths with $200 \mathrm{mg} / \mathrm{L}$ of ivermectin, culminating in $100 \%$ fish mortality within $2 \mathrm{hr}$ of exposure. However, therapeutic baths containing $500 \mathrm{mg} / \mathrm{L}$ of albendazole caused a mortality of $6.6 \%$ within $24 \mathrm{hr}$, but did not change the behaviour of exposed fish, while $125 \mathrm{mg} / \mathrm{L}$ of levamisole caused no fish mortality or behavioural changes.

\section{DISCUSSION}

All the concentrations of levamisole $(50-125 \mathrm{mg} / \mathrm{L})$, albendazole $(500-2,000 \mathrm{mg} / \mathrm{L})$ and ivermectin $(200-350 \mathrm{mg} / \mathrm{L})$ in the in vitro assays were $100 \%$ effective against $A$. spatulatus,
N. janauachensis, M. boegeri and L. brinkmanni of C. macropomum. Similarly, $100 \mathrm{mg} / \mathrm{L}$ of levamisole and $0.031 \mathrm{mg} / \mathrm{L}$ of ivermectin were also $100 \%$ effective in vitro against Gyrodactylus sp. of Oncorhynchus mykiss (Santamarina et al., 1991). Hirazawa et al. (2000) also reported $100 \%$ efficacy of $20 \mathrm{mg} / \mathrm{L}$ of levamisole against Heterobothrium okamotoi of Takifugu rubripes. However, albendazole had been not tested in vitro against monogeneans, at the present moment. Exposure to levamisole induces changes in the haptor of monogeneans (Taraschewski, Renner, \& Mehlhorn, 1988), causing these parasites to detach from the gills of fish. The anthelmintic effect of albendazole is that it inhibits microtubule polymerization by binding to $\beta$-tubulin, impairing the supply of cellular nutrients to helminths (Martins et al., 2017). The mode of action of avermectins such as ivermectin is paralysis of helminths (Collymore et al., 2014).

Managing and controlling monogenean infestations are a constant challenge in fish farming, given the limited availability of effective anthelmintic drugs (Morales-Serna et al., 2018). We attribute the in vitro efficacy of mebendazole $(125-200 \mathrm{mg} / \mathrm{L})$ and praziquantel $(5-20 \mathrm{mg} / \mathrm{L})$ against monogeneans of $C$. macropomum to the solvent DMSO, given the low water solubility, and hence, low availability of both drugs (Liu et al., 2018; Swanepoel, Liebenberg, Devarakonda, \& Villiers, 2003). Moreover, has been reported in vitro efficacy of DMSO against the monogeneans Cichlidogyrus tilapiae, Cichlidogyrus thurstonae, Cichlidogyrus halli and Scutogyrus Iongicornis of Oreochromis niloticus (Hashimoto et al., 2016). Morales-Serna et al. (2018) also suggest effects of alcohol used as solvent for praziquantel $(2.5-20.0 \mathrm{mg} / \mathrm{L})$ against monogeneans Neobenedenia melleni. In vitro efficacy of $0.005 \mathrm{mg} / \mathrm{L}$ of mebendazole and $2.5 \mathrm{mg} / \mathrm{L}$ of praziquantel against Dactylogyrus vastator of Carassius auratus has also been reported (Zhang et al., 2014). Hirazawa et al. (2013) observed 80\%-100\% in vitro efficacy of $0.5 \mathrm{mg} / \mathrm{L}$ of praziquantel against Benedenia seriolae and N. melleni of Seriola quinqueradiata and Seriola dumerili. Given the in vitro efficacy of $2.5-20.0 \mathrm{mg} / \mathrm{L}$ praziquantel against Tagia ecuadori and $N$. melleni, thus was suggested that a low concentration of this drug can be used in long-term therapeutic baths (Morales-Serna et al., 2018). Although praziquantel paralyses monogeneans, it does not always kill them (Hirazawa et al., 2013; Morales-Serna et al., 2018). In view of the growing interest in controlling and treating monogenean infestations using

TAB LE 3 Prevalence $(P)$ and mean abundance $(M A)$ of monogeneans on gills of Colossoma macropomum exposed to anthelmintic drugs

\begin{tabular}{|c|c|c|c|c|c|c|}
\hline \multirow{2}{*}{$\frac{\text { Treatments }}{\text { Parasite species }}$} & \multicolumn{2}{|c|}{ Controls $(n=30)$} & \multicolumn{2}{|c|}{$125 \mathrm{mg} / \mathrm{L}$ of levamisole $(n=30$} & \multicolumn{2}{|c|}{$\begin{array}{l}500 \mathrm{mg} / \mathrm{L} \text { of albendazole } \\
(n=30)\end{array}$} \\
\hline & $P(\%)$ & $M A \pm S D$ & $P(\%)$ & $M A \pm S D$ & $\mathrm{P}(\%)$ & $M A \pm S D$ \\
\hline Anacanthorus spatulatus & 100 & $47.3 \pm 26.4^{\mathrm{a}}$ & 96.7 & $7.0 \pm 6.3^{b}$ & 100 & $39.6 \pm 30.6^{\mathrm{a}}$ \\
\hline Mymarothecium boegeri & 96.7 & $14.5 \pm 13.2^{\mathrm{a}}$ & 16.7 & $0.8 \pm 2.5^{b}$ & 33.3 & $2.5 \pm 5.1^{\mathrm{b}}$ \\
\hline Notozothecium janauachensis & 100 & $46.9 \pm 55.5^{\mathrm{a}}$ & 73.3 & $5.1 \pm 6.6^{b}$ & 90.0 & $14.2 \pm 13.1^{b}$ \\
\hline
\end{tabular}

Note. Mean values followed by different letters on the same line indicate differences between treatments according to Dunn's test $(p<0.05)$. 
low-cost, effective and commercially available anthelmintic drugs, it is therefore highly desirable for such drugs to be used directly in the water of fish breeding tanks.

Safe anthelmintic drugs that can be administered in therapeutic baths are suitable for use in fish farming. However, in the therapeutic baths of C. macropomum with $200 \mathrm{mg} / \mathrm{L}$ of ivermectin, $100 \%$ fish mortality occurred within $2 \mathrm{hr}$ of exposure, while $500 \mathrm{mg} / \mathrm{L}$ of albendazole caused a fish mortality rate of $6.6 \%$ within $24 \mathrm{hr}$ of exposure. Piaractus mesopotamicus has also reportedly exhibited good drug tolerance after $30 \mathrm{~min}$ of exposure to $50-500 \mathrm{mg} / \mathrm{L}$ of albendazole (Onaka et al., 2003). Therapeutic baths with $1.8 \mathrm{mg} / \mathrm{L}$ of ivermectin also caused $100 \%$ mortality of Sparus aurata after $96 \mathrm{hr}$ of exposure (Mladineo et al., 2006). Santamarina et al. (1991) reported that therapeutic baths with $0.031 \mathrm{mg} / \mathrm{L}$ of ivermectin caused a high mortality rate among 0 . mykiss after just a few minutes of exposure. Danio rerio also reportedly suffered $100 \%$ mortality after exposure to 0.007 and $0.009 \mathrm{mg} / \mathrm{L}$ of ivermectin, as did Catla catla exposed to $0.007 \mathrm{mg} / \mathrm{L}$ of this drug, due to neurotoxicity and hepatotoxicity (Thiripurasundari et al., 2014; Varó et al., 2010). These reported results indicate that ivermectin is not a good anthelmintic drug for control and treatment, given its high toxicity to fish even at low concentrations.

In intensive fish farming, even when good management practices are employed to prevent monogenean infestations, treatments are often necessary to control mortality rates or to implement sanitation programs during at least some stage of fish breeding. Therefore, knowledge about suitable strategies to control and treat against these parasitic diseases is essential. Therapeutic baths with $500 \mathrm{mg} / \mathrm{L}$ of albendazole were only $48.6 \%$ effective against monogeneans of C. macropomum after $24 \mathrm{hr}$ of exposure. In contrast, $125 \mathrm{mg} / \mathrm{L}$ of levamisole was $88.2 \%$ effective against monogeneans because it blocked neuromuscular junctions and stimulated parasympathetic and sympathetic ganglia in the hosts (Martins et al., 2017), causing the parasites to detach from the host gills. Thirty minute therapeutic baths with $500 \mathrm{mg} / \mathrm{L}$ of albendazole were $32.7 \%$ effective, while $200 \mathrm{mg} / \mathrm{L}$ of albendazole was $46.5 \%$ affective against Anacanthorus penilabiatus of P. mesopotamicus (Onaka et al., 2003). In addition, $3 \mathrm{~h}$ therapeutic baths with $100 \mathrm{mg} / \mathrm{L}$ of levamisole were effective against Gyrodactylus sp. of O. mykiss (Santamarina et al., 1991), and 10-18 min baths with $20-50 \mathrm{mg} / \mathrm{L}$ of levamisole were effective against Urocleidus vistulensis of Silurus glanis (Szekely \& Molnar, 1990). Therefore, albendazole efficacy depends on the concentration and exposure time of the hosts to the drug.

In conclusion, although the treatment in vitro with albendazole, ivermectin and levamisole was $100 \%$ effective against monogeneans of C. macropomum, only levamisole showed good efficacy in therapeutic baths, since albendazole showed low efficacy and exposure to ivermectin was highly toxic to fish. Therefore, we recommend the use of long duration antiparasitic therapeutic baths with $125 \mathrm{mg} / \mathrm{L}$ of levamisole to control monogeneans of $C$. macropomum in fish farming.

\section{ACKNOWLEDGEMENTS}

The authors gratefully acknowledge to National Council for Scientific and Technological Development (CNPq, Brazil), for the productivity research grant awarded to Dr. M. Tavares-Dias (\# 303013/2015-0).

\section{CONFLICT OF INTEREST}

The authors declare no conflict of interest.

\section{ETHICAL APPROVAL}

This study was approved by the Ethics Committee on Animal Use of Embrapa Amapá (Protocol Nº 013/2018-CEUA/CPAFAP) and was conducted in accordance with the principles of the Brazilian College of Animal Experimentation (COBEA).

\section{ORCID}

Marcos Tavares-Dias (iD https://orcid.org/0000-0002-8376-1846

\section{REFERENCES}

Bader, C., Chelladurai, J. J., Starling, D. E., Jones, D. E., \& Brewer, M. T. (2017). Assessment of in vitro killing assays for detecting praziquantel induced death in Posthodiplostomum minimum metacercariae. Experimental Parasitology, 181, 70-74. https://doi.org/10.1016/j. exppara.2017.07.008

Bush, A. O., Lafferty, K. D., Lotz, J. M., \& Shostak, A. W. (1997). Parasitology meets ecology on its own terms: Margolis et al. revisited. The Journal of Parasitology, 83(4), 575-583. https://doi. org/10.2307/3284227

Collymore, C., Watral, V., White, J. R., Colvin, M. E., Rasmussen, S. Tolwani, R. J., \& Kent, M. L. (2014). Tolerance and efficacy of emamectin benzoate and ivermectin for the treatment of Pseudocapillaria tomentosa in laboratory Zebrafish (Danio rerio). Zebrafish, 11, 490497. https://doi.org/10.1089/zeb.2014.1021

Eiras, J. C., Takemoto, R. M., \& Pavanelli, G. C. (2006). Métodos de estudo e técnicas laboratoriais em parasitologia de peixes ( $2^{\text {a }}$ ed.). Maringá, Brazil: Eduem.

FAO - Food and Agriculture Organization of the United Nations (2018). The state of world fisheries and aquaculture 2018. Meting the sustainable development goals. Rome, Italy: FAO.

Hashimoto, G. S., Neto, F. M., Ruiz, M. L., Acchile, M., Chagas, E. C., Chaves, F. C. M., \& Martins, M. L. (2016). Essential oils of Lippia sidoides and Mentha piperita against monogenean parasites and their influence on the hematology of Nile tilapia. Aquaculture, 450, 182-186. https://doi.org/10.1016/j.aquaculture.2015.07.029

Hirazawa, N., Akiyama, K., \& Umeda, N. (2013). Differences in sensitivity to the anthelmintic praziquantel by the skin-parasitic monogeneans Benedenia seriolae and Neobenedenia girellae. Aquaculture, 404-405, 59-64. https://doi.org/10.1016/j.aquaculture.2013.04.021

Hirazawa, N., Ohtaka, T., \& Hata, K. (2000). Challenge trials on the anthelmintic effect of drugs and natural agents against the monogenean Heterobothrium okamotoi in the tiger puffer Takifugu rubripes. Aquaculture, 188, 1-13. https://doi.org/10.1016/ S0044-8486(00)00334-3

Kim, K. H., \& Choi, E. S. (1998). Treatment of Microcotyle sebastis (Monogenea) on the gills of cultured rockfish (Sebastes schlelegelii) 
with oral administration of mebendazole and bithionol. Aquaculture, 167, 115-121. https://doi.org/10.1016/S0044-8486(98)00300-7

Liu, Y., Wang, T., Ding, W., Dong, C., Wang, X., Chen, J., \& Li, Y. (2018). Dissolution and oral bioavailability enhancement of praziquantel by solid dispersions. Drug Delivery and Translational Research, 8, 580590. https://doi.org/10.1007/s13346-018-0487-7

Martins, M. L., Mourino, J. L. P., Chagas, E. C. C., Silva, B. C., Fujimoto, R. Y., \& Pádua, S. B. (2017). Ectoparasitários na aquicultura. In B. Baldisserotto, L. C. Gomes, B. M. Heinzmann \& M. A. Cunha (Eds.), Farmacologia aplicada a aquicultura (pp. 127-181). Santa Maria, CA: UFSM.

Martins, M. L., Onaka, E. M., Moraes, F. R., \& Fujimoto, R. Y. (2001). Mebendazole treatment against Anacanthorus penilabiatus (monogenea, Dactylogyridae) gill parasite of cultivated Piaractus mesopotamicus (Osteichthyes, Characidae) in Brazil. efficacy and Phematology. Acta Parasitologica, 46, 332-336.

Mladineo, I., Marsic-lucic, J., \& Buzancic, M. (2006). Toxicity and gross pathology of ivermectin bath treatment in sea bream Sparus aurata, L. Ecotoxicology and Environmental Safety, 63, 438-442. https://doi. org/10.1016/j.ecoenv.2005.02.015

Morales-Serna, F. N., Chapa-López, M., Martínez-Brown, J. M., IbarraCastro, L., Medina-Guerrero, R. M., \& Fajer-Ávila, E. J. (2018). Efficacy of praziquantel and a combination anthelmintic (Adecto ${ }^{\circledR}$ ) in bath treatments against Tagia ecuadori and Neobenedenia melleni (Monogenea), parasites of bullseye puffer fish. Aquaculture, 492, 361-368. https://doi.org/10.1016/j.aquaculture.2018.04.043

Onaka, E. M., Martins, M. L., \& Moraes, F. R. (2003). Eficácia do albendazol e praziquantel no controle de Anacanthorus penilabiatus (Monogenea: Dactylogyridae), parasito de pacu Piaractus mesopotamicus (Osteichthyes: Characidae). I. banhos terapêuticos. Boletim do Instituto De Pesca, 29, 101-107.

Santamarina, M. T., Tojo, J., Ubeira, F. M., Quinteiro, P., \& Sanmartin, M. L. (1991). Anthelmintic treatment against Gyrodactylus sp. infecting rainbow trout Oncorhynchus mykiss. Diseases of Aquatic Organisms, 10, 39-43. https://doi.org/10.3354/dao010039

Sitjà-Bobadilla, A., Felipe, M. C., \& Alvarez-Pellitero, P. (2006). In vivo and in vitro treatments against Sparicotyle chrysophrii (Monogenea: Microcotylidae) parasitizing the gills of gilthead sea bream (Sparus aurata L.). Aquaculture, 261(3), 856-864. https://doi.org/10.1016/j. aquaculture.2006.09.012

Soares, B. V., Neves, L. R., Oliveira, M. S. B., Chaves, F. C. M., Dias, M. K. R., Chagas, E. C., \& Tavares-Dias, M. (2017). Antiparasitic activity of the essential oil of Lippia alba on ectoparasites of Colossoma macropomum (tambaqui) and its physiological and histopathological effects. Aquaculture, 452, 107-114. https://doi.org/10.1016/j. aquaculture.2015.10.029
Sommerville, C., Endris, R., Bell, T. A., Ogawa, K., Buchmann, K., \& Sweeney, D. (2016). World association for the advancement of veterinary parasitology (WAAVP) guideline for testing the efficacy of ectoparasiticides for fish. Veterinay Parasitology, 219, 84-99. https:// doi.org/10.1016/j.vetpar.2015.11.003.

Swanepoel, E., Liebenberg, W., Devarakonda, B., \& Villiers, M. M. (2003). Developing a discriminating dissolution test for three mebendazole polymorphs based on solubility diferences. Die Pharmazie, 58, 117-121.

Szekely, C., \& Molnar, K. (1990). Treatment of Ancylodiscoides vistulensis monogenean infestations of the European catfish (Silurus glanis). Bulletin of the European Association of Fish Pathologists, 10, 74-77.

Taraschewski, H., Renner, C., \& Mehlhorn, H. (1988). Treatment of fish parasites. Parasitology Research, 74, 281-289. https://doi. org/10.1007/BF00539579

Tavares-Dias, M., \& Martins, M. L. (2017). An overall estimation of losses caused by diseases in the Brazilian fish farms. Journal of Parasitic Diseases, 41, 913-918. https://doi.org/10.1007/s12639-017-0938-y

Thiripurasundari, M., Sathya, K., Uma, A., Srinivasan, M. R., Rajasekar, P. A. (2014). Comparative study on the toxicity of ivermectin in zebra fish and catla fish models. Indo American Journal of Pharmaceutical Research, 4, 2231-6876.

Varó, I., Rigos, G., Navarro, J. C., Ramo, J. D., Calduch-Giner, J., Hernández, A., ... Torreblanca, A. (2010). Effect of ivermectin on the liver of gilthead sea bream Sparus aurata: A proteomic approach. Chemosphere, 80, 570-577. https://doi.org/10.1016/j.chemosphere.2010.04.030

Zar, J. H. (2010). Biostatistical analysis (5th ed.). Englewood Cliffs, NJ: Prentice-Hall.

Zhang, X. P., Li, W. X., Ai, T. S., Zou, H., Wu, S. G., \& Wang, G. T. (2014). The efficacy of four common anthelmintic drugs and traditional Chinese medicinal plant extracts to control Dactylogyrus vastator (Monogenea). Aquaculture, 420-421, 302-307. https://doi. org/10.1016/j.aquaculture.2013.09.022

Zuskova, E., Piackova, V., Machova, J., Chupani, L., Steinbach, C., Stara, A., \& Velisek, J. (2018). Efficacy and toxicity of praziquantel in helminth-infected barbel (Barbus barbus L.). Journal of Fish Diseases, 41, 643-649. https://doi.org/10.1111/jfd.12764

How to cite this article: Alves CMG, Nogueira JN, Barriga IB, dos Santos JR, Santos GG, Tavares-Dias M. Albendazole, levamisole and ivermectin are effective against monogeneans of Colossoma macropomum (Pisces: Serrasalmidae). J Fish Dis. 2019;42:405-412. https://doi.org/10.1111/jfd.12952 